\title{
Epithelial sphingolipid sorting is insensitive to reorganization of the Golgi by nocodazole, but is abolished by monensin in MDCK cells and by brefeldin A in Caco-2 cells
}

\author{
Gerrit van Meer and Wouter van 't Hof' \\ Department of Cell Biology, Medical School AZU H02.314, University of Utrecht, 3584 CX Utrecht, The Netherlands \\ *Present address: Cornell University Medical College, 1300 York Avenue, New York, NY 10021, USA
}

\section{SUMMARY}

In epithelial MDCK and Caco-2 cells, short-chain analogs of glucosylceramide and sphingomyelin are delivered from the Golgi to the cell surface with different apical/basolateral polarities, which results in an apical enrichment of the glycolipid glucosylceramide over the phospholipid sphingomyelin. Here, we have interfered with the integrity of the Golgi complex in various ways and tested the effects on lipid transport and sorting. Nocodazole, which depolymerizes microtubules, dispersed the Golgi over the cytoplasm of MDCK cells and reduced transport of newly synthesized $\mathrm{C}_{6}-\mathrm{NBD}-(\mathrm{N}$ 6[7-nitro-2,1,3-benzoxadiazol-4-yl]aminocaproyl)-glucosylceramide and $\mathrm{C}_{6}$-NBD-sphingomyelin to the apical surface by $40 \%$. The lipids were not mistargeted to the basolateral surface and upon removal of nocodazole, apical transport recovered. Nocodazole did not affect the apical enrichment of glucosylceramide over sphingomyelin. The ionophore monensin led to swelling of the Golgi of MDCK cells and inhibited lipid transport to the cell surface by $30-50 \%$. Whereas sphingomyelin transport to both surface domains was equally affected, monensin mainly inhibited apical transport of glucosylceramide. At 10-20 $\mu \mathrm{M}$ of monensin, the two lipids displayed the same polarity of delivery: sorting between the two lipids was abolished. Brefeldin A at $1 \mu \mathrm{g} / \mathrm{ml}$, which resulted in disruption of the Golgi in HepG2 cells and completely inhibited protein secretion, had no inhibitory effect on transport of the $\mathrm{C}_{6}$-NBD-lipids to the surface. The same was observed in Caco-2 cells. However, brefeldin A selectively shifted transport of sphingomyelin towards the apical direction which abolished the apical enrichment of glucosylceramide over sphingomyelin. Caco-2 cells were used because in MDCK cells brefeldin A did not change Golgi structure nor lipid transport and sorting. In summary, modification of the Golgi by monensin and brefeldin A, but not nocodazole, interfered with the sorting event by which glucosylceramide is enriched over sphingomyelin in the transport pathway from the Golgi to the apical surface.

Key words: epithelia, sphingolipid, lipid transport, lipid sorting, nocodazole, monensin, brefeldin

\section{INTRODUCTION}

After intracellular synthesis, short-chain analogs of glucosylceramide (GlcCer) and sphingomyelin (SM) reach the cell surface of MDCK and Caco-2 epithelial cells with apical/basolateral polarities of $\geq 2$ and $\leq 1$, respectively (van Meer et al., 1987; van 't Hof and van Meer, 1990; van 't Hof et al., 1992). Because this difference in polarity reflects the lipid distribution that has been observed in intestinal epithelial cells in vivo (see Simons and van Meer, 1988), the intracellular sorting of the one sphingolipid analog from the other appears to mimick that of their native counterparts.

The bulk of GlcCer and SM is synthesized in cis-Golgi (Futerman et al., 1990; Futerman and Pagano, 1991; Jeckel et al., 1990; Jeckel et al., 1992). In addition, all available evidence points to a vesicular mode of transport of the two lipids to the cell surface whereby they are oriented towards the lumen of the transport compartments (Kobayashi and Pagano, 1989; Kobayashi et al., 1992; van Meer and Burger, 1992). How and where GlcCer reaches this lumen after synthesis on the cytoplasmic aspect of the cis-Golgi (Coste et al., 1986; Futerman and Pagano, 1991; Trinchera et al., 1991; Jeckel et al., 1992) is unknown at present. Assuming that GlcCer translocation occurred in the Golgi (Karrenbauer et al., 1990; van 't Hof and van Meer, 1990; Kobayashi et al., 1992), the different polarities of delivery to the two plasma membrane domains of epithelial cells have been interpreted as reflecting a sorting event in the luminal leaflet of the membrane of the trans-Golgi network (TGN). GlcCer would be enriched over SM in an apical precursor microdomain, due to its enhanced tendency to form hydrogen bonds (van Meer et al., 1987; Simons and van Meer, 1988). 
The aim of the present work was to learn about the mechanism of epithelial lipid sorting by interfering with Golgi structure and with Golgi-plasma membrane transport. For this, we have applied three agents to intact epithelial cells under conditions where they are known to disrupt the organization of the Golgi and interfere with protein transport in those cells: nocodazole and monensin to MDCK cells and brefeldin A (BFA) to MDCK, HepG2 and Caco-2 cells. Nocodazole depolymerizes microtubules (De Brabander et al., 1976) and disperses the Golgi (Kreis, 1990). The monovalent cationophore monensin leads to vacuolation of the Golgi and interferes with intracellular transport and processing of glycoproteins (Mollenhauer et al., 1990) at the level of the medial-Golgi. BFA causes a partial redistribution of the Golgi cisternae into a mixed ER-Golgi compartment in a number of cell types. At the same time it blocks transport of newly synthesized proteins to the cell surface (Klausner et al., 1992).

The influence of the three agents on lipid sorting was tested in an assay that compares the polarity of delivery of newly synthesized $\mathrm{C}_{6}$-NBD-(N-6[7-nitro-2,1,3-benzoxadiazol-4-yl]aminocaproyl)-GlcCer to the cell surface to that of $\mathrm{C}_{6}$-NBD-SM (van Meer et al., 1987; van 't Hof and van Meer, 1990; van 't Hof et al., 1992). The assay quantitates the influence of each agent on the biosynthesis of the two sphingolipid analogs and on the transport of each species to the apical and to the basolateral cell surface. The resulting apical/basolateral ratios of delivery and the relative polarity of GlcCer/SM show whether or not either agent affected epithelial lipid sorting.

\section{MATERIALS AND METHODS}

\section{Cells}

Monolayers of MDCK strain II cells (3-day-old) and Caco-2 cells (7-day-old) were cultured on Costar Transwell and TranswellCOL filters, respectively (van 't Hof et al., 1992). HepG2 cells were grown as before and were used at $80 \%$ confluence, approximately $4 \times 10^{5}$ cells per $35 \mathrm{~mm}$ diameter dish (Jeckel et al., 1992).

\section{Sphingolipid transport assay}

Delivery of $\mathrm{C}_{6}$-NBD-sphingolipids to the cell surface was assayed as before (van Meer et al., 1987). HPLC-purified D-erythro-C6NBD-ceramide (van 't Hof et al., 1992) was incorporated into the apical cell surface for $0.5 \mathrm{~h}$ at $10^{\circ} \mathrm{C}$ from liposomes $(19.5 \mathrm{nmol}$ ceramide in $0.75 \mathrm{ml}, 13 \mathrm{~mol} \%$ in sonicated phosphatidylcholine liposomes) in Hanks' balanced salt solution without bicarbonate, $10 \mathrm{mM}$ Hepes, pH 7.4 (HBSS). When added from the basal side, $52 \mathrm{nmol}$ ceramide were applied in $2 \mathrm{ml}$. Unless indicated otherwise, cells were allowed to accumulate $\mathrm{C}_{6}-\mathrm{NBD}-\mathrm{GlcCer}$ and $\mathrm{C}_{6}$ $\mathrm{NBD}-\mathrm{SM}$ for $2 \mathrm{~h}$ at $20^{\circ} \mathrm{C}$. Delivery to the apical and basolateral plasma membrane of newly synthesized $\mathrm{C}_{6}$-NBD-lipids at $37^{\circ} \mathrm{C}$ was routinely assayed during $1 \mathrm{~h}$ by continuous depletion by HBSS+BSA (1\%, w/v). Each transport incubation was followed by a wash with $\mathrm{HBSS}+\mathrm{BSA}$ for $0.5 \mathrm{~h}$ at $10^{\circ} \mathrm{C}$. Fluorescent lipids were extracted from the pooled apical media, the pooled basal media and the cell monolayer on the filter ( 2 filters per measurement). After TLC, the fractions of each fluorescent lipid in the apical medium (apical transport) and the basal medium (basolateral transport) were quantitated. Radioactive ceramide analogs were applied and analyzed as described (van 't Hof et al., 1992). The s.d. of the averaged transport values was $\leq 20 \%$ of these averages. The transport values served to calculate the polarity of delivery of each lipid and the relative polarity of GlcCer over SM, as described before (van 't Hof and van Meer, 1990). In experiments without a $2 \mathrm{~h}, 20^{\circ} \mathrm{C}$ incubation, transport was lower than in standard experiments, but the levels of synthesis, the transport ratios and the polarities were similar.

\section{Drug incubations}

Before ceramide addition, cells were preincubated with nocodazole $(1 \mathrm{~h})$ or BFA $(0.5 \mathrm{~h})$ in growth medium in the $\mathrm{CO}_{2}$-incubator at $37^{\circ} \mathrm{C}$. Drugs were present on both sides of cell monolayers on filters, but were absent from the ceramide suspension and from the $10^{\circ} \mathrm{C}$ wash. The relevant solvent was added to the corresponding media of controls. Nocodazole (Sigma, St. Louis, MO) was diluted to $33 \mu \mathrm{M}$ from a $1,000 \times$ stock in $\mathrm{Me}_{2} \mathrm{SO}$ (De Brabander et al., 1976). It was observed that in the absence of BSA or serum (some) nocodazole precipitated from the HBSS. In a control experiment where the liposome incubation was at $0^{\circ} \mathrm{C}$ instead of $10^{\circ} \mathrm{C}$ and where the (calculated) nocodazole concentration was $66 \mu \mathrm{M}$, the results were not different from those obtained under standard conditions (Table 1). Monensin (Eli Lilly, Indianapolis, IN), diluted to $10 \mu \mathrm{M}$ from a $100 \times$ ethanol stock, was added at the start of the $37^{\circ} \mathrm{C}$ transport incubation. BFA (Sigma, St. Louis, MO) was used at $1 \mu \mathrm{g} / \mathrm{ml}(3.6 \mu \mathrm{M})$ from a 100 $\times$ ethanol stock.

\section{Fluorescence microscopy}

Cell monolayers on filters were fixed in $1 \%$ formaldehyde for 0.5 $\mathrm{h}$ at $10^{\circ} \mathrm{C}$, mounted under a coverslip in Mowiol and viewed by confocal laser scanning microscopy on a MRC-600 instrument (Bio-Rad Lasersharp, Ltd, Abingdon, GB) mounted onto a Zeiss Axioplan microscope.

\section{Materials}

BSA fraction V was purchased from Sigma Chemical Co. (St.

Table 1. Sphingolipid transport and polarity in nocodazole-treated MDCK cells

\begin{tabular}{|c|c|c|c|c|c|c|c|}
\hline \multirow[b]{3}{*}{ Condition } & \multicolumn{3}{|c|}{ GlcCer } & \multicolumn{3}{|c|}{ SM } & \multirow{3}{*}{$\begin{array}{c}\text { GlcCer/SM } \\
\begin{array}{c}\text { Relative } \\
\text { polarity }\end{array}\end{array}$} \\
\hline & \multicolumn{2}{|c|}{ Transport (\% in BSA) } & \multirow{2}{*}{$\begin{array}{c}\text { Polarity } \\
\text { (Apical/basal) } \\
\end{array}$} & \multicolumn{2}{|c|}{ Transport (\% in BSA) } & \multirow{2}{*}{$\begin{array}{c}\text { Polarity } \\
\text { (Apical/basal) }\end{array}$} & \\
\hline & Apical & Basal & & Apical & Basal & & \\
\hline Control & 43 & 27 & 1.8 & 33 & 42 & 0.8 & $2.4 \pm 1.0$ \\
\hline Nocodazole & 27 & 27 & 1.0 & 21 & 39 & 0.5 & $2.0 \pm 0.5$ \\
\hline Nocodazole & $0.6 \pm 0.2$ & $1.1 \pm 0.3$ & & $0.6 \pm 0.1$ & $1.0 \pm 0.2$ & & \\
\hline Control & & & & & & & \\
\hline
\end{tabular}

At the end of the control experiment, 3 pmol $\mathrm{C}_{6}$-NBD-GlcCer and 19 pmol $\mathrm{C}_{6}$-NBD-SM had been synthesized per $10^{6}$ cells. Synthesis in the presence of nocodazole: GlcCer, $(1.3 \pm 0.4) \times$ control value, $\mathrm{SM},(1.1 \pm 0.1) \times$ control value $(n=28)$. Transport values are the mean of 19 measurements in 12 experiments. Polarities and nocodazole/control ratios ( \pm s.d.) were calculated from these, plus 9 measurements performed without the $20^{\circ} \mathrm{C}$ incubation. 
Louis, MO). C6-NBD-ceramide was from Molecular Probes, Inc. (Junction City, OR). $\mathrm{C}_{8} / \mathrm{C}_{8}-\left[{ }^{3} \mathrm{H}\right]$ ceramide was a kind gift of Felix Wieland, Heidelberg. Cell culture plastics and filters were from Costar (Cambridge, MA). Chemicals and solvents were of analytical grade and obtained from Riedel-de Haën (Seelze, FRG).

\section{RESULTS}

\section{Influence of nocodazole on Golgi structure and lipid transport to the surface of MDCK cells}

In order to cause complete depolymerization of the microtubules in MDCK cells, the use of nocodazole (De Brabander et al., 1976) was combined with a cold treatment (Parton et al., 1991). MDCK cells were preincubated with $33 \mu \mathrm{M}$ nocodazole for $1 \mathrm{~h}$ at $37^{\circ} \mathrm{C}$ prior to addition of $\mathrm{C}_{6-}$ NBD-ceramide at $10^{\circ} \mathrm{C}$. This treatment disrupted the structure of the Golgi complex, as viewed by fluorescence microscopy of the $\mathrm{C}_{6}$-NBD-lipids (Fig. 1A,B). In contrast to the regular, clustered appearance of the Golgi in the control, after nocodazole the fluorescence aggregated into bright fluorescent dots randomly distributed over the cytoplasm. After a subsequent incubation for $2 \mathrm{~h}$ at $20^{\circ} \mathrm{C}$ to accumulate $\mathrm{C}_{6}$-NBD-GlcCer and $\mathrm{C}_{6}$-NBD-SM in the Golgi (van Meer et al., 1987), transport of these products to the two cell surfaces at $37^{\circ} \mathrm{C}$ was also found to be affected by nocodazole. Apical appearance of both lipids was inhibited to $60 \%$ of the control level, whereas no change in basolateral delivery was observed (Table 1). Consequently, the apical/basal polarities of delivery were reduced to the same extent for $\mathrm{C}_{6}$-NBD-GlcCer and $\mathrm{C}_{6}$-NBD-SM, which left the relative polarity of GlcCer versus SM unaffected (Table 1). This implies that nocodazole did not interfere with sorting of the one lipid from the other.

The inhibitory effect of nocodazole on the transport of both lipids was noticeable within $10 \mathrm{~min}$ from the start of the $37^{\circ} \mathrm{C}$ transport incubation (Fig. 2). However, whereas basolateral transport recovered within the hour, apical transport did not. When at this timepoint nocodazole was removed, apical lipid transport recovered to $75 \%$ of the controls within $1 \mathrm{~h}$, showing that the inhibitory effect of nocodazole was essentially reversible. Removal of nocodazole did not result in a significant increase of transport to the basolateral surface. A control experiment (van 't Hof and van Meer, 1990) demonstrated that the tight junctions were tight for lipids throughout the nocodazole experiment. Nocodazole specifically interfered with the delivery of the two sphingolipids to the apical domain.

\section{Influence of the side of $\mathrm{C}_{6}-\mathrm{NBD}$-ceramide addition on the polarity of lipid transport}

Nocodazole changed the distribution of the Golgi elements over the cytoplasm. This should not have affected uniform labeling of the various elements by $\mathrm{C}_{6}-\mathrm{NBD}$-ceramide, as $\mathrm{C}_{6}$-NBD-ceramide rapidly diffuses all over the cytoplasm before it concentrates in the Golgi (Lipsky and Pagano, $1985 \mathrm{~b})$. If this is true, the polarity of the transport of the $\mathrm{C}_{6}$-NBD-products to the two cell surface domains should be independent of the side where the ceramide entered the cell. To test this, $\mathrm{C}_{6}$-NBD-ceramide was added to MDCK and Caco-2 cells from the basal instead of the apical side of the filter. Unexpectedly, the polarity of transport of $\mathrm{C}_{6}$ -

Table 2. Dependence of sphingolipid polarity on the sidedness of ceramide addition

\begin{tabular}{|c|c|c|c|c|c|c|c|}
\hline \multirow[b]{3}{*}{ Condition } & \multicolumn{3}{|c|}{ GlcCer } & \multicolumn{3}{|c|}{ SM } & \multirow{3}{*}{$\begin{array}{c}\text { GlcCer/SM } \\
\begin{array}{c}\text { Relative } \\
\text { polarity }\end{array}\end{array}$} \\
\hline & \multicolumn{2}{|c|}{ Transport (\% in BSA) } & \multirow{2}{*}{$\begin{array}{c}\text { Polarity } \\
\text { (Apical/basal) }\end{array}$} & \multicolumn{2}{|c|}{ Transport (\% in BSA) } & \multirow{2}{*}{$\begin{array}{c}\text { Polarity } \\
\text { (Apical/basal) }\end{array}$} & \\
\hline & Apical & Basal & & Apical & Basal & & \\
\hline \multicolumn{8}{|l|}{ MDCK: } \\
\hline Apical & 53 & 33 & 1.7 & 39 & 48 & 0.8 & $2.3 \pm 0.5$ \\
\hline Basal & 42 & 37 & 1.2 & 27 & 54 & 0.6 & $2.3 \pm 0.8$ \\
\hline Basal & $0.8 \pm 0.1$ & $1.2 \pm 0.2$ & & $0.7 \pm 0.1$ & $1.1 \pm 0.1$ & & \\
\hline \multicolumn{8}{|l|}{$\overline{\text { Apical }}$} \\
\hline $37^{\circ} \mathrm{C}$, apical & & & 1.3 & & & 0.7 & $2.0 \pm 0.4$ \\
\hline \multicolumn{8}{|c|}{ Caco-2, $\mathrm{C}_{6}$-NBD-ceramide: } \\
\hline Apical & 58 & 16 & 3.7 & 35 & 31 & 1.2 & $3.5 \pm 1.5$ \\
\hline Basal & 41 & 37 & 1.1 & 22 & 50 & 0.4 & $2.7 \pm 0.9$ \\
\hline Basal & $0.7 \pm 0.0$ & $2.4 \pm 0.3$ & & $0.6 \pm 0.1$ & $1.7 \pm 0.2$ & & \\
\hline \multicolumn{8}{|c|}{$\overline{\text { Apical }}$} \\
\hline \multicolumn{8}{|c|}{ Caco- $2, \mathrm{C}_{8}-\left[{ }^{14} \mathrm{C}\right]$ ceramide: } \\
\hline Apical & & & 3.5 & & & 0.40 & $9.0 \pm 1.3$ \\
\hline Basal & & & 0.5 & & & 0.07 & $7.1 \pm 1.0$ \\
\hline \multicolumn{8}{|c|}{ Caco-2, $\mathrm{C}_{8} / \mathrm{C}_{8}-\left[{ }^{3} \mathrm{H}\right]$ ceramide: } \\
\hline Apical & & & 3.3 & & & 1.1 & $3.0 \pm 0.3$ \\
\hline Basal & & & 2.0 & & & 0.9 & $2.2 \pm 0.5$ \\
\hline
\end{tabular}

MDCK: synthesis in the control, 5 pmol C6-NBD-GlcCer and 29 pmol C6-NBD-SM per $10^{6}$ cells. Synthesis after basal addition: GlcCer, $(0.6 \pm 0.3) \times$ control value; SM, $(0.8 \pm 0.2) \times$ control value $(n=8)$. Transport values and ratios, $n=8$. (Relative) polarities, $n=16$. In the $37^{\circ} \mathrm{C}$ experiment, liposomes were not added in a $10^{\circ} \mathrm{C}$ preincubation, but directly to the apical medium of the $1 \mathrm{~h}, 37^{\circ} \mathrm{C}$ incubation. Synthesis of GlcCer, $(8 \pm 2) \times$ control value; SM, $(6 \pm 1)$ $\times$ control value $(n=18)$.

Caco-2: synthesis in the control, 30 pmol C6-NBD-GlcCer and 26 pmol $\mathrm{C}_{6}-\mathrm{NBD}-\mathrm{SM}$ per $10^{6}$ cells. Synthesis after basal addition: GlcCer, $(0.7 \pm 0.3) \times$ control value; SM, $(0.6 \pm 0.2) \times$ control value $(n=5)$. Control synthesis from $\mathrm{C}_{8}-\left[{ }^{14} \mathrm{C}\right]$ ceramide, of which an 8 -fold higher concentration had been added to allow accurate quantitation (van 't Hof et al., 1992), 29 pmol of GlcCer and 168 pmol of SM per $10^{6}$ cells $(n=2)$. After basal addition: GlcCer, $1.0 \times$ control value; SM, $0.8 \times$ control value. Control synthesis from $\mathrm{C}_{8} / \mathrm{C}_{8}-\left[{ }^{3} \mathrm{H}\right]$ ceramide (van 't Hof et al., 1992 ), 3 pmol of GlcCer and 6 pmol of SM per $10^{6}$ cells $(n=2)$. After basal addition: GlcCer and SM, $0.7 \times$ control value. 

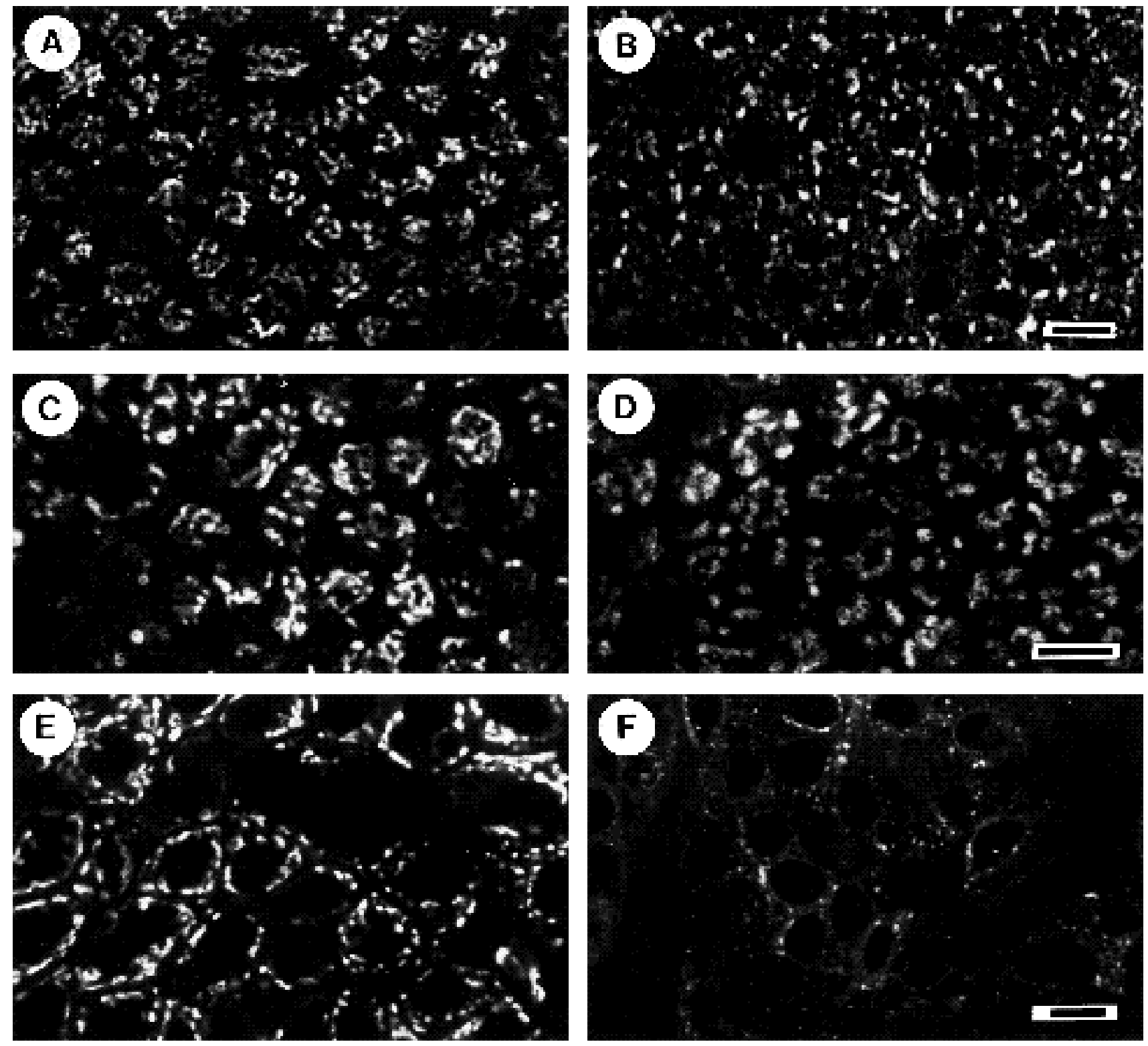

Fig. 1. Morphology of the Golgi complex after drug treatment as monitored by $\mathrm{C}_{6}-\mathrm{NBD}$-sphingolipids. Monolayers of MDCK cells on Transwells were incubated with or without nocodazole for $1 \mathrm{~h}$ at $37^{\circ} \mathrm{C}$. C6-NBD-ceramide addition for $2 \mathrm{~h}$ at $10^{\circ} \mathrm{C}$ resulted in selective NBD-staining of the Golgi complex (Lipsky and Pagano, 1985b; van Meer et al., 1987) in the control (A). After nocodazole, the Golgi fluorescence aggregated into bright fluorescent dots that were dispersed over the cytoplasm (B). Incubation of MDCK cells for $0.5 \mathrm{~h}$ at $37^{\circ} \mathrm{C}$ with or without monensin, followed by incorporation of $\mathrm{C}_{6}-\mathrm{NBD}$-ceramide, showed that, compared to the control (C), after monensin the Golgi appeared swollen (D). Caco-2 monolayers were incubated with or without BFA for $0.5 \mathrm{~h}$ at $37^{\circ} \mathrm{C}$, before addition of $\mathrm{C}_{6}-\mathrm{NBD}$-ceramide for $2 \mathrm{~h}$ at $10^{\circ} \mathrm{C}$. In the control (E), NBD-fluorescence accumulated in a pattern of bright dots around the nucleus, typical of the Golgi complex of these cells (van 't Hof and van Meer, 1990). After BFA (F), this pattern had completely disappeared and small dots of fluorescence were superimposed on a haze of dispersed fluorescence in the cytoplasm. Bars, $10 \mu \mathrm{m}$.

NBD-GlcCer and $\mathrm{C}_{6}-\mathrm{NBD}-\mathrm{SM}$ decreased by $25 \%$ in MDCK and even by $70 \%$ in Caco-2 (Table 2). This was the consequence of a reduction of apical transport and an increase in transport to the basolateral surface. The effect was overcome by adding $\mathrm{C}_{6}$-NBD-ceramide at $37^{\circ} \mathrm{C}$, which gave rise to an intermediate polarity of delivery (Table 2). When the less water-soluble $\mathrm{C}_{8}-\left[{ }^{14} \mathrm{C}\right]$ ceramide was used as a precursor in Caco- 2 cells, the reduction in polarity at $10^{\circ} \mathrm{C}$ was more pronounced, whereas the effect was less for the readily diffusible $\mathrm{C}_{8} / \mathrm{C}_{8}-\left[{ }^{3} \mathrm{H}\right]$ ceramide (Table 2 ).
Some cell growth occurred on the inside wall of the filter holder. These cells were only reached by apically added C6-NBD-ceramide and contributed fluorescent products to the apical medium only. However, in a direct experiment these cells accounted for only about one-third of the sidedness effect in the MDCK cells. So the major reason for the reduced polarity of delivery after basal addition of $\mathrm{C}_{6-}$ NBD-ceramide appears to be that diffusion of this ceramide into the cell is too slow to label the various parts of the Golgi evenly. The action of nocodazole on C6-NBD-lipid 


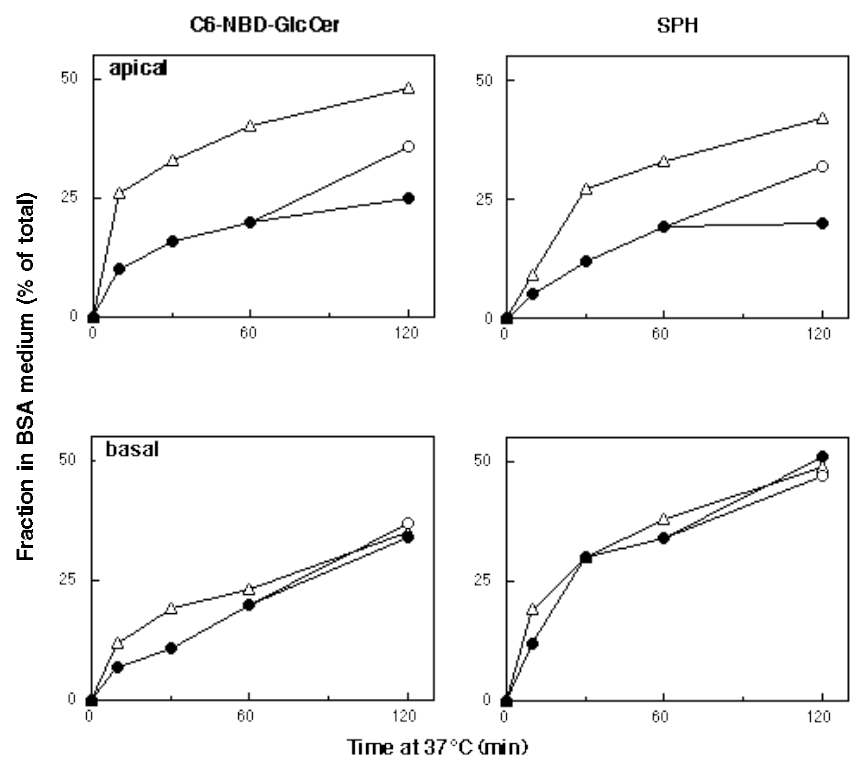

Fig. 2. Time-course of transport of $\mathrm{C}_{6}-\mathrm{NBD}-\mathrm{GlcC}$ er and $\mathrm{C}_{6}$ NBD-SM (SPH) to the plasma membrane of MDCK cells in the presence $(\mathbf{)})$ or absence $(\triangle, \bigcirc)$ of nocodazole. After pretreatment of MDCK cells with or without $33 \mu \mathrm{M}$ nocodazole and accumulation of $\mathrm{C}_{6}-\mathrm{NBD}-\mathrm{GlcC}$ r and $\mathrm{C}_{6}-\mathrm{NBD}-\mathrm{SM}$ in the Golgi as described under Materials and methods, at time 0 the transport incubation was started by warming the cells to $37^{\circ} \mathrm{C}$. After varying time intervals, apical and basolateral HBSS+BSA were harvested, the cells were washed with $\mathrm{BSA}$ at $10^{\circ} \mathrm{C}$ and the media and cells were analyzed for fluorescent lipids. For measurements of recovery from nocodazole $(\bigcirc)$, at time $60 \mathrm{~min}$ the HBSS+BSA+nocodazole was collected and, after a wash, simply replaced by HBSS+BSA without nocodazole for an additional $1 \mathrm{~h}$. Data represent the mean of 3 experiments, s.d. $10-20 \%$ of each value.

transport and sorting was found to be independent of this sidedness effect in control experiments, where the ceramide was added to the basal side or where it was present throughout the $37^{\circ} \mathrm{C}$ incubation and thus uniformly labeled the Golgi (not shown).

\section{Influence of monensin on lipid transport and sorting in MDCK cells}

As a second method of interfering with the structural and functional integrity of the Golgi, cells were treated with monensin. Monensin induced a subtle but consistent change in the morphology of the Golgi complex in MDCK cells, as monitored by NBD-fluorescence. During $0.5 \mathrm{~h}$ at $37^{\circ} \mathrm{C}$, monensin induced vacuolation of the Golgi (Fig. 1C,D). This was accompanied by a differential effect on the delivery of $\mathrm{C}_{6}$-NBD-GlcCer and $\mathrm{C}_{6}$-NBD-SM to the cell surface. With increasing concentrations of monensin, a gradual inhibition of transport to the cell surface was observed for both lipids (Fig. 3). However, while transport of $\mathrm{C}_{6^{-}}$ NBD-SM was equally inhibited in both directions, a preferential decrease in apical transport of $\mathrm{C}_{6}-\mathrm{NBD}-\mathrm{GlcCer}$ resulted in a two-fold reduction of the apical/basal polarity of GlcCer delivery (Table 3). At monensin concentrations of $10 \mu \mathrm{M}$ or more, the difference in the polarity of the two lipids had decreased to a level where the relative polarity
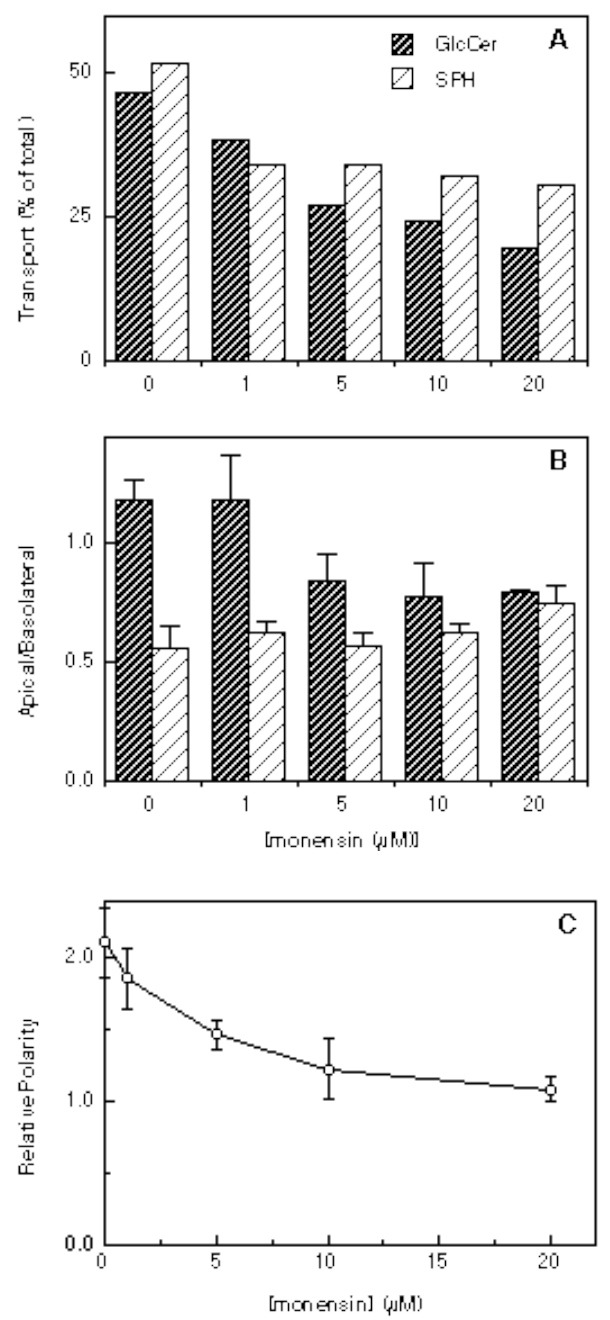

Fig. 3. Concentration dependence of the monensin effects on transport to the cell surface (A), polarity of delivery (B) and relative polarity $(\mathrm{C})$ of $\mathrm{C}_{6}$-NBD-GlcCer (GlcCer) and $\mathrm{C}_{6}$-NBD$\mathrm{SM}(\mathrm{SPH})$ in MDCK cells. MDCK cells were incubated with $\mathrm{C}_{6}-$ NBD-ceramide containing liposomes in the presence of $1 \% \mathrm{BSA}$ and varying concentrations of monensin for $1 \mathrm{~h}$ at $37^{\circ} \mathrm{C}$. Data are the mean of duplicate measurements in 3 experiments $(n=6)$. Error bars indicate s.d. Synthesis under these conditions in the control, 44 pmol C6-NBD-GlcCer and 156 pmol C6-NBD-SM per $10^{6}$ cells.

approached unity: $\mathrm{C}_{6}$-NBD-GlcCer was no longer sorted from $\mathrm{C}_{6}$-NBD-SM. A $1 \mathrm{~h}$ preincubation with $10 \mu \mathrm{M}$ monensin, followed by a transport incubation in the absence of monensin, resulted in a recovery of the relative polarity to 1.5. Recovery increased if, after the monensin preincubation, the cells were incubated in medium without monensin before the start of the transport incubation (not shown).

\section{Influence of BFA on lipid sorting in Caco-2 cells}

As a third way of interfering with the structure of the Golgi, we used BFA. In HepG2 cells, BFA $(1 \mu \mathrm{g} / \mathrm{ml})$ completely inhibited secretion of a variety of plasma proteins and plasma membrane delivery of vesicular stomatitis virus $\mathrm{G}$ protein (Oda et al., 1990). In addition, it led to a virtually complete redistribution of trans-Golgi enzymes to the ER, 


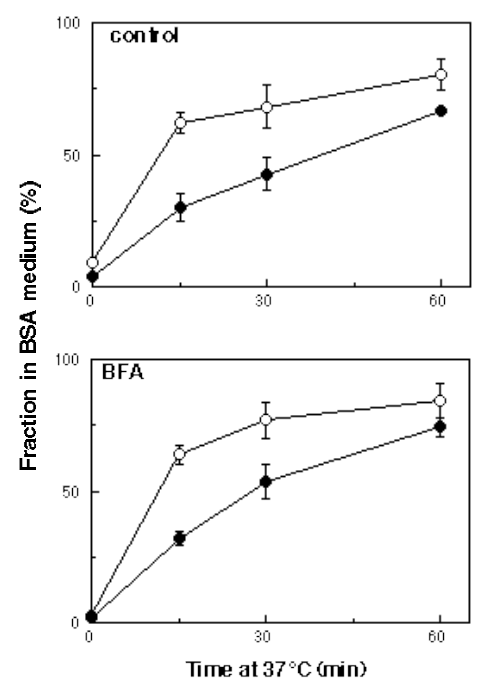

Fig. 4. Time-course of transport of $\mathrm{C}_{6}-\mathrm{NBD}-\mathrm{GlcCer}(\mathrm{O})$ and $\mathrm{C}_{6-}$ NBD-SM (O) to the surface of HepG2 cells in the absence (top) and presence (bottom) of BFA at $37^{\circ} \mathrm{C}$. After a $0.5 \mathrm{~h}$ preincubation with or without BFA, HepG2 cells on plastic dishes were incubated with $\mathrm{C}_{6}-\mathrm{NBD}$-ceramide for $0.5 \mathrm{~h}$ at $10^{\circ} \mathrm{C}$, followed by an incubation at $37^{\circ} \mathrm{C}$ in $\mathrm{HBSS}+\mathrm{BSA}$ containing BFA or not. The fraction of each lipid in the HBSS+BSA has been plotted against the duration of the transport incubation. Error bars represent the s.d. $(n=7)$. Synthesis after $1 \mathrm{~h}$ : control, 88 pmol $\mathrm{C}_{6-}$ NBD-GlcCer and 250 pmol C6-NBD-SM per $10^{6}$ cells, +BFA, $(1.1 \pm 0.2)$ and $(1.8 \pm 0.3) \times$ control, respectively.

as assayed by cell fractionation (Strous et al., 1993). First we tested whether transport of $\mathrm{C}_{6}-\mathrm{NBD}-\mathrm{GlcCer}$ or $\mathrm{C}_{6-}$ NBD-SM to the cell surface still occurred. No difference in their kinetics was observed (Fig. 4), although glucosyltransferase redistributed to the ER under these conditions (Strous et al., 1993), whereas SM synthase did not (Fig. 5). When the cells, after addition of $\mathrm{C}_{6}$-NBD-ceramide, were incubated for $2-3 \mathrm{~h}$ at $10^{\circ} \mathrm{C}$, a background of only $11 \% \pm$ $4 \%(n=8)$ of both products was depleted from the cell surface in the presence of BFA, as compared to $10 \% \pm 5 \%$ $(n=12)$ in the control, showing that the temperature dependence of transport was maintained.

In agreement with the literature (Low et al., 1992), BFA at $1 \mu \mathrm{g} / \mathrm{ml}$ was found not to affect the structure of the Golgi complex in MDCK cells. Even $30 \mu \mathrm{g} / \mathrm{ml}$ BFA had a minimal effect on synthesis and transport of SM (both -20\%), with no effect on GlcCer. The relative polarity (sorting)

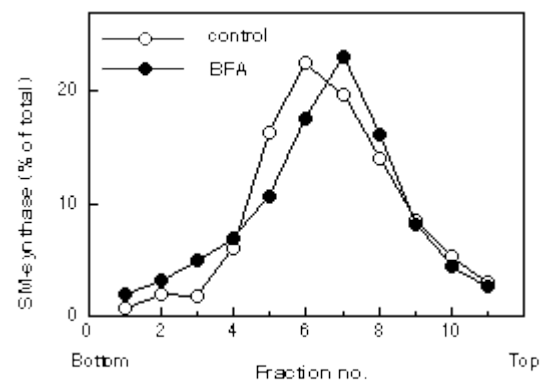

Fig. 5. Localization of sphingomyelin synthase activity on sucrose gradients of a postnuclear supernatant of HepG2 cells that had been preincubated for $0.5 \mathrm{~h}$ with $(\bigcirc ; n=7)$ or without $(\bigcirc ; n=5) 1$ $\mu \mathrm{g}$ per $\mathrm{ml}$ of BFA. Cells were homogenized and fractionated on 0.7 M-1.5 M linear sucrose gradients, after which sphingomyelin synthase activity was measured as described before (Jeckel et al., 1992). s.d. in the top fractions was $3-4 \%$.

remained unchanged at $2.0 \pm 0.3$ from 1 to $30 \mu \mathrm{g} / \mathrm{ml}$ BFA. In contrast, BFA did have a severe effect on Golgi structure in Caco-2 cells, as shown in Fig. 1E,F. The distinct perinuclear patches of Golgi observed under control conditions (van 't Hof and van Meer, 1990) disappeared upon BFA addition, resulting in dispersion of NBD-fluorescence over the cytoplasm, though some punctate pattern persisted. Transport of the $\mathrm{C}_{6}-\mathrm{NBD}$-sphingolipids to the cell surface was unaffected, but the polarity of delivery had increased. The increase was relatively minor for $\mathrm{C}_{6}$-NBD-GlcCer, i.e. $1.2 \times$, but it was dramatic for $\mathrm{C}_{6}-\mathrm{NBD}-\mathrm{SM}$, increasing from 0.8 to 3.9 (Table 4 ). By this, the polarity of $\mathrm{C}_{6}-\mathrm{NBD}-\mathrm{SM}$ had become identical to that of $\mathrm{C}_{6}-\mathrm{NBD}-\mathrm{GlcC}$, changing the value of the relative polarity from 3.4 to 0.9 . A leakage test (van 't Hof and van Meer, 1990) showed that the cell monolayer remained tight in the presence of BFA. As in the case of monensin in MDCK, addition of BFA to Caco-2 cells led to a complete loss of intracellular lipid sorting. However, while monensin reached this effect by decreasing the polarity of $\mathrm{C}_{6}-\mathrm{NBD}-\mathrm{GlcC}$ er, BFA increased the polarity of $\mathrm{C}_{6}-\mathrm{NBD}-\mathrm{SM}$ instead.

\section{DISCUSSION}

In the present paper we have tested how three agents that interfere with Golgi structure influence transport and sort-

Table 3. Sphingolipid transport and polarity in monensin-treated MDCK cells

\begin{tabular}{|c|c|c|c|c|c|c|c|}
\hline \multirow[b]{3}{*}{ Condition } & \multicolumn{3}{|c|}{ GlcCer } & \multicolumn{3}{|c|}{ SM } & \multirow{3}{*}{$\begin{array}{c}\text { GlcCer/SM } \\
\begin{array}{c}\text { Relative } \\
\text { polarity }\end{array}\end{array}$} \\
\hline & \multicolumn{2}{|c|}{ Transport (\% in BSA) } & \multirow{2}{*}{$\begin{array}{c}\text { Polarity } \\
\text { (Apical/basal) }\end{array}$} & \multicolumn{2}{|c|}{ Transport (\% in BSA) } & \multirow{2}{*}{$\begin{array}{c}\text { Polarity } \\
\text { (Apical/basal) }\end{array}$} & \\
\hline & Apical & Basal & & Apical & Basal & & \\
\hline Control & 53 & 31 & 1.7 & 42 & 45 & 0.9 & $2.0 \pm 0.3$ \\
\hline Monensin & 27 & 30 & 0.9 & 28 & 34 & 0.9 & $1.1 \pm 0.2$ \\
\hline Monensin & $0.5 \pm 0.1$ & $0.9 \pm 0.2$ & & $0.7 \pm 0.1$ & $0.7 \pm 0.2$ & & \\
\hline Control & & & & & & & \\
\hline
\end{tabular}

Synthesis in the control experiment was 3 pmol $\mathrm{C}_{6}-\mathrm{NBD}-\mathrm{GlcC}$ and 18 pmol $\mathrm{C}_{6}$-NBD-SM per $10^{6}$ cells. Synthesis in the presence of monensin: GlcCer, $(0.8 \pm 0.1) \times$ control value; SM, $(1.3 \pm 0.2) \times$ control value $(n=9)$. Transport values, $n=5$. Monensin/control ratios and polarities were calculated from these, plus four measurements performed without $20^{\circ} \mathrm{C}$ pre-incubation. 
Table 4. Sphingolipid transport and polarity in BFA-treated Caco-2 cells

\begin{tabular}{|c|c|c|c|c|c|c|c|}
\hline \multirow[b]{3}{*}{ Condition } & \multicolumn{3}{|c|}{ GlcCer } & \multicolumn{3}{|c|}{$\mathrm{SM}$} & \multirow{3}{*}{$\begin{array}{c}\text { GlcCer/SM } \\
\begin{array}{c}\text { Relative } \\
\text { polarity }\end{array}\end{array}$} \\
\hline & \multicolumn{2}{|c|}{ Transport (\% in BSA) } & \multirow{2}{*}{$\begin{array}{c}\text { Polarity } \\
\text { (Apical/basal) }\end{array}$} & \multicolumn{2}{|c|}{ Transport (\% in BSA) } & \multirow{2}{*}{$\begin{array}{c}\text { Polarity } \\
\text { (Apical/basal) }\end{array}$} & \\
\hline & Apical & Basal & & Apical & Basal & & \\
\hline Control & 48 & 18 & 2.8 & 25 & 36 & 0.8 & $3.4 \pm 0.7$ \\
\hline BFA & 49 & 16 & 3.4 & 43 & 12 & 3.9 & $0.9 \pm 0.1$ \\
\hline BFA & $1.1 \pm 0.1$ & $0.9 \pm 0.1$ & & $1.8 \pm 0.2$ & $0.3 \pm 0.1$ & & \\
\hline$\overline{\text { Control }}$ & & & & & & & \\
\hline
\end{tabular}

Synthesis in control was 12 pmol C 6 -NBD-GlcCer and 22 pmol $\mathrm{C}_{6}$-NBD-SM per $10^{6}$ cells. Synthesis in the presence of BFA: GlcCer, $(1.5 \pm 0.3) \times$ control value; $\mathrm{SM},(0.8 \pm 0.1) \times$ control value. All numbers represent the average of 8 measurements without $20^{\circ} \mathrm{C}$ pre-incubations.

ing of newly synthesized sphingolipids to the cell surface of epithelial cells.

\section{Nocodazole}

Nocodazole selectively reduced apical $\mathrm{C}_{6}$-NBD-lipid transport (Table 1; Fig. 2). In intestinal epithelium (see Achler et al., 1989), and in MDCK and Caco-2 cells, microtubule depolymerization drastically slowed protein transport to the apical, but not the basolateral, surface (Rindler et al., 1987; Eilers et al., 1989; Parczyk et al., 1989; Breitfeld et al., 1990; Hunziker et al., 1990; Matter et al., 1990; van Zeijl and Matlin, 1990; Gilbert et al., 1991), with little effect in non-epithelial cells (see Stults et al., 1989). The efficiency of apical transport may depend on microtubules, because they maintain the Golgi close to the apical surface (Kreis, 1990). Alternatively, they may provide tracks for transport vesicles to follow (Kelly, 1990; Vale, 1990), which would allow apical vesicles to traverse the terminal web efficiently in the apical pole of epithelial cells.

Nocodazole selectively interfered with apical transport of $\mathrm{C}_{6}$-NBD-SM. This confirms the notion that SM is transported by vesicles exclusively (Kobayashi and Pagano, 1989; Futerman et al., 1990; Helms et al., 1990; Jeckel et al., 1990; Jeckel et al., 1992). Transport of $\mathrm{C}_{6}$-NBD-GlcCer and $\mathrm{C}_{6}$-NBD-SM was reduced to the same extent, implying also that apical transport of $\mathrm{C}_{6}$-NBD-GlcCer was vesicular (cf. Kobayashi and Pagano, 1989; Kobayashi et al., 1992). The selective inhibition of apical transport implies that the nocodazole-sensitive transport step is after the bifurcation in the epithelial exocytic pathway in the TGN. Thus, the two lipids must have been together in the TGN. Nocodazole did not affect the relative polarity. Sorting of GlcCer from SM still occurred. Apparently, microtubules are not involved in the process, and moreover, each of the scattered Golgi clusters in the presence of nocodazole must have retained its sorting capacity.

Inhibition of apical lipid transport did not enhance basolateral delivery. The inhibition, therefore, most likely occurred after budding of apical vesicles. If nocodazole would have blocked budding, it is difficult to see how the $\mathrm{C}_{6}$-NBD-lipids destined for the apical surface would have been prevented from leaking into the ongoing basolateral route. Clearly, apical vesicles were not mistargeted to the basolateral surface. The same has been concluded for membrane proteins (Salas et al., 1986; Gutmann et al., 1989; van Zeijl and Matlin, 1990; however, cf. Rindler et al., 1987). Microtubule depolymerization increased the amount of certain apical proteins on the basolateral surface (Achler et al., 1989; Eilers et al., 1989; Breitfeld et al., 1990). Normally, these specific proteins, at least in part, pass over the basolateral surface on their way to the apical surface, and the increase in their basolateral concentration after microtubule depolymerization appeared to be caused by a concomitant block in basal-to-apical transcytosis (Matter et al., 1990; Hunziker et al., 1990; Gilbert et al., 1991). For this kinetic effect the term "missorting" seems inaccurate, since apparently neither the sorting event in the TGN nor the specificity of targeting of apical vesicles was affected. In contrast, microtubule disruption did disturb the polarity of protein secretion (Parczyk et al., 1989; Boll et al., 1991; de Almeida and Stow, 1991).

\section{Sidedness of ceramide addition}

When $\mathrm{C}_{6}$-NBD-ceramide was added from the basal instead of the apical side, the polarity of delivery of the $\mathrm{C}_{6}-\mathrm{NBD}$ lipid products decreased (Table 2). This is inconsistent with the assumption that $\mathrm{C}_{6}$-NBD-ceramide should freely diffuse all over the cell before concentrating in the Golgi (Lipsky and Pagano, 1985a,b; van Meer et al., 1987; van 't Hof and van Meer, 1990). Rather it suggests that $\mathrm{C}_{6}-\mathrm{NBD}$-ceramide diffused into the cell only slowly and was preferentially metabolized in a Golgi subcompartment closest to the side of addition. Because a basal TGN would receive more basal transport components by recycling from the basal endocytic route, the ratio of apical-over-basal membrane transport from this Golgi would be lower than that of an apical Golgi. Since lipids equilibrate between pathways, this would result in a decreased polarity of delivery for both $\mathrm{C}_{6}-\mathrm{NBD}$-products from a basal TGN. The idea of Golgi subcompartments is supported by a more pronounced sidedness effect in the columnar Caco-2 cells, than in the cuboidal MDCK cells. In Caco- 2 cells at 7 days, Golgi complexes are situated at random locations along the apical-basal axis (van 't Hof and van Meer, 1990), but in MDCK cells, the Golgi complex as a whole resides on the apical side of the nucleus (van Meer et al., 1987). Also, the effect was extreme for $\mathrm{C}_{8}-\left[{ }^{14} \mathrm{C}\right]$ ceramide, which is more natural and less watersoluble than $\mathrm{C}_{6}$-NBD-ceramide, and less for the highly diffusible $\mathrm{C}_{8} / \mathrm{C}_{8}-\left[{ }^{3} \mathrm{H}\right]$ ceramide. Finally, the effect was not caused by a double layer of cells, only one of which would take up ceramide and contribute a signal. Irregularities were not observed in MDCK monolayers and were rare in Caco2 monolayers.

GlcCer synthesis occurs on the cytosolic surface of the Golgi (Coste et al., 1986; Futerman and Pagano, 1991; Trinchera et al., 1991) and newly synthesized short chain 
GlcCer but not SM was accessible in permeabilized $\mathrm{CHO}$ and HepG2 cells (Jeckel et al., 1992). $\mathrm{C}_{6}$-NBD-GlcCer could also be depleted by BSA from the cytosolic surface in basolaterally permeabilized MDCK cells (Table I in Kobayashi et al., 1992). When $\mathrm{C}_{6}$-NBD-lipids were transported to the cell surface at $37^{\circ} \mathrm{C}$ and BSA was added at $10^{\circ} \mathrm{C}$, in intact cells equal amounts of the two lipids were found on the cell surface (van Meer et al., 1987; van 't Hof and van Meer, 1990). However, in the permeabilized cells, 3 times more $\mathrm{C}_{6}$-NBD-GlcCer was extracted than $\mathrm{C}_{6}$-NBD$\mathrm{SM}$. From the $\mathrm{C}_{6}-\mathrm{NBD}-\mathrm{GlcC}$ er polarity, it is clear that there was increased $\mathrm{C}_{6}$-NBD-GlcCer extraction from the basolateral, permeabilized, surface, while the extraction had not come to a halt yet. From its exchangeability from the cytosolic surface and its enhanced water solubility, newly synthesized $\mathrm{C}_{6}-\mathrm{NBD}-\mathrm{GlcCer}$ would be expected to equilibrate between intracellular organelles, a possible mechanism for GlcCer transport to the plasma membrane (Sasaki, 1990). This is inconsistent with the nocodazole data. In addition, if $\mathrm{C}_{6}$-NBD-GlcCer would have equilibrated over the Golgi, its polarity of delivery should have been insensitive to the sidedness of ceramide addition. This was not the case (Table 2). Apparently, in intact cells GlcCer is translocated into the Golgi lumen shortly after or during synthesis. Evidence for sequestration in isolated Golgi vesicles has been found in one study (Karrenbauer et al., 1990) but not in another (Jeckel et al., 1992). The site and mechanism of GlcCer translocation remain to be characterized.

\section{Monensin}

The monovalent cationophore monensin is the first agent that we have found to interfere with epithelial lipid sorting. Monensin has been reported to cause cellular accumulation of GlcCer and lactosylceramide between 4 and $24 \mathrm{~h}$ (MillerProdraza and Fishman, 1984; Saito et al., 1985; van Echten and Sandhoff, 1989; Gundlach et al., 1991), and it has been speculated that the drug slows transport through the medialGolgi. In support of this idea, monensin caused a 30-60\% reduction in transport of $\mathrm{C}_{6}$-NBD-GlcCer and $-\mathrm{SM}$ to the cell surface on a $1 \mathrm{~h}$ timescale (Lipsky and Pagano, 1985a; Table 3), while on a timescale of $8 \mathrm{~h}$, this was not observed for the complex glycosphingolipid $\mathrm{G}_{\mathrm{D} 1 \mathrm{a}}$ (Miller-Prodraza and Fishman, 1984). To explain the remaining transport, it has been suggested that a secretory pathway would exist, bypassing the Golgi (Mollenhauer et al., 1990). However, it is well possible that monensin abolished some ionic requirement for the efficient complex glycosylation of glycosphingolipids and glycoproteins in the medial/transGolgi and interfered with the efficiency, but not the specificity, of the intra- and post-Golgi transport steps. In that case, the lipid sorting would be dependent on the ionic conditions in the TGN. How this relates to the observed delay in the delivery of apical proteins (at 1-10 $\mu \mathrm{M}$, RodriguezBoulan et al., 1984; Daniels and Edwardson, 1988) and the virtual block in basolateral transport of a membrane protein (at $10 \mu \mathrm{M}$, Alonso-Caplen and Compans, 1983) and two secretory proteins (already at $200 \mathrm{nM}$, Parczyk and Kondor-Koch, 1989), remains to be elucidated.

\section{BFA}

In many cell types BFA causes Golgi cisternae, but not the
TGN, to fuse with the ER (Klausner et al., 1992). However, part of the Golgi retains its identity as a separate compartment (De Lemos-Chiarandini et al., 1992; Hendricks et al., 1992; Hidalgo et al., 1992). In HepG2 cells, some Golgi enzymes, including glucosyltransferase, redistributed to the ER (Strous et al., 1991, 1993), but SM-synthase did not (Fig. 5). Therefore, the punctate fluorescence pattern after $\mathrm{C}_{6}$-NBD-ceramide addition, in HepG2 just like in Caco-2 (Fig. 1E,F), probably was caused by synthesis of $\mathrm{C}_{6}-\mathrm{NBD}-$ SM in a Golgi cluster that had maintained its identity, but not its location, in the presence of BFA. In CHO cells, a redistribution of the SM-synthase to the ER was hypothesized from an observed rise in SM biosynthesis (Brüning et al., 1992). However, in HepG2 such a rise occurred without redistribution (Figs 4, 5). Moreover, SM synthesis decreased in Caco-2 (Table 4) and neuronal cells (van Echten et al., 1990). The inhibition of glycosphingolipid processing by BFA at the level of the GalNAc-transferase (van Echten et al., 1990; Young et al., 1990) was taken to suggest a location of this enzyme in a late Golgi compartment. In the light of the new data on the persistence of part of the Golgi in the presence of BFA, an interpretation of synthesis data in terms of enzyme location seems premature.

In contrast to the BFA block in protein transport, newly synthesized cholesterol from the ER still reached the plasma membrane, most likely by a vesicular mechanism (Urbani and Simoni, 1990). Also transport of $\mathrm{C}_{6}-\mathrm{NBD}-\mathrm{GlcC}$ (er and $\mathrm{C}_{6}-\mathrm{NBD}-\mathrm{SM}$ to the surface of HepG2 and Caco- 2 cells was unaffected (Fig. 4; Table 4). However, BFA abolished lipid sorting (Table 4). Interestingly, BFA is a monovalent cationophore like monensin (Zizi et al., 1991), but its action on lipid sorting differed from the monensin effect. Monensin simply neutralized the apical enrichment of $\mathrm{C}_{6}$-NBDGlcCer without influencing $\mathrm{C}_{6}$-NBD-SM, while BFA increased the polarity of both, but to different extents. The observation that nocodazole and the side of $\mathrm{C}_{6}$-NBDceramide addition influenced transport and polarity of $\mathrm{C}_{6-}$ NBD-GlcCer and of $\mathrm{C}_{6}$-NBD-SM in identical ways provides strong support for vesicular transport of both lipids to the plasma membrane, while the specific effect of nocodazole on apical transport localizes the lipid sorting event to the TGN. Monensin and BFA induced a loss of lipid sorting. However, before it can be concluded that the ionic conditions in the TGN are a crucial parameter in the lipid sorting mechanism, it will be important to establish whether in the presence of the drugs the $\mathrm{C}_{6}$-NBD-lipids still pass through the TGN as the final station on the way out.

We thank Henry Laning and Marion Thielemans for fine experimental contributions. We are grateful to Guido Husson (Biorad) for the confocal micrographs of Fig. 1A,B and to Willem Hage (Hubrecht Laboratory) for the micrographs in Fig. 1C-F. G.v.M. was supported by a senior fellowship from the Royal Netherlands Academy of Arts and Sciences.

\section{REFERENCES}

Achler, C., Filmer, D., Merte, C. and Drenckhahn, D. (1989). Role of microtubules in polarized delivery of apical membrane proteins to the brush border of the intestinal epithelium. J. Cell Biol. 109, 179-189.

Alonso-Caplen, F.V. and Compans, R.W. (1983). Modulation of 
glycosylation and transport of viral membrane glycoproteins by a sodium ionophore. J. Cell Biol. 97, 659-668.

Boll, W., Partin, J.S., Katz, A.I., Caplan, M.J. and Jamieson, J.D. (1991). Distinct pathways for basolateral targeting of membrane and secretory proteins in polarized epithelial cells. Proc. Nat. Acad. Sci. USA 88, 8592-8596.

Breitfeld, P.P., McKinnon, W.C. and Mostov, K.E. (1990). Effect of nocodazole on vesicular traffic to the apical and basolateral surfaces of polarized MDCK cells. J. Cell Biol. 111, 2365-2373.

Brüning, A., Karrenbauer, A., Schnabel, E. and Wieland, F.T. (1992). Brefeldin A-induced increase of sphingomyelin synthesis.J. Biol. Chem. 267, 5052-5055.

Coste, H., Martel, M.B. and Got, R. (1986). Topology of glucosylceramide synthesis in Golgi membranes from porcine submaxillary glands. Biochim. Biophys. Acta 858, 6-12.

Daniels, P.U. and Edwardson, J.M. (1988). Intracellular processing and transport of influenza-virus envelope proteins in Madin-Darby canine kidney cells. Effects of the carboxylic ionophores monensin and nigericin. Biochem. J. 252, 693-700.

de Almeida, J.B. and Stow, J.L. (1991). Disruption of microtubules alters polarity of basement membrane proteoglycan secretion in epithelial cells. Am. J. Physiol. 260, C691-C700.

De Brabander, M.J., Van de Veire, R.M.L., Aerts, F.E.M., Borgers, M. and Janssen, P.A.J. (1976). The effects of methyl [5-(2thienylcarbonyl)-1H-benzimidazol-2-yl]carbamate, (R 17934; NSC 238159), a new synthetic antitumoral drug interfering with microtubules, on mammalian cells cultured in vitro. Cancer Res. 36, 905-916.

De Lemos-Chiarandini, C., Ivessa, N.E., Black, V.H., Tsao, Y.S., Gumper, I. and Kreibich, G. (1992). A Golgi-related structure remains after the brefeldin A-induced formation of an ER-Golgi hybrid compartment. Eur. J. Cell Biol.58, 187-201.

Eilers, U., Klumperman, J. and Hauri, H.-P. (1989). Nocodazole, a microtubule-active drug, interferes with apical protein delivery in cultured intestinal epithelial cells (Caco-2). J. Cell Biol. 108, 13-22.

Futerman, A.H., Stieger, B., Hubbard, A.L. and Pagano, R.E. (1990). Sphingomyelin synthesis in rat liver occurs predominantly at the cis and medial cisternae of the Golgi apparatus. J. Biol. Chem. 265, 86508657.

Futerman, A.H. and Pagano, R.E. (1991). Determination of the intracellular sites and topology of glucosylceramide synthesis in rat liver. Biochem. J. 280, 295-302.

Gilbert, T., Le Bivic, A., Quaroni, A. and Rodriguez-Boulan, E. (1991). Microtubular organization and its involvement in the biogenetic pathways of plasma membrane proteins in Caco-2 intestinal epithelial cells. J. Cell Biol.113, 275-288.

Gundlach, B., Helland, R., Radsak, K. and Wiegandt, H. (1991). Analyses of the effect of monensin on glycosphingolipid metabolism. Biochem. J. 279, 753-757.

Gutmann, E.J., Niles, J.L., McCluskey, R.T. and Brown, D. (1989). Colchicine-induced redistribution of an apical membrane glycoprotein (gp330) in proximal tubules. Am. J. Physiol. 257, C397-C407.

Helms, J.B., Karrenbauer, A., Wirtz, K.W.A., Rothman, J.E. and Wieland, F.T. (1990). Reconstitution of steps in the constitutive secretory pathway in permeabilized cells. Secretion of glycosylated tripeptide and truncated sphingomyelin. J. Biol. Chem. 265, 2002720032.

Hendricks, L.C., McClanahan, S.L., McCaffery, M., Palade, G.E. and Farquhar, M.G. (1992). Golgi proteins persist in the tubulovesicular remnants found in brefeldin A-treated pancreatic acinar cells. Eur. J. Cell Biol. 58, 202-213.

Hidalgo, J., Garcia-Navarro, R., Gracia-Navarro, F., Perez-Vilar, J. and Velasco, A. (1992). Presence of Golgi remnant membranes in the cytoplasm of brefeldin A-treated cells. Eur. J. Cell Biol. 58, 214-227.

Hunziker, W., Mâle, P. and Mellman, I. (1990). Differential microtubule requirements for transcytosis in MDCK cells. EMBO J. 9, 3515-3525.

Jeckel, D., Karrenbauer, A., Birk, R., Schmidt, R.R. and Wieland, F. (1990). Sphingomyelin is synthesized in the cis Golgi. FEBS Lett. 261, 155-157.

Jeckel, D., Karrenbauer, A., Burger, K.N.J., van Meer, G. and Wieland, F. (1992). Glucosylceramide is synthesized at the cytosolic surface of various Golgi subfractions. J. Cell Biol. 117, 259-267.

Karrenbauer, A., Jeckel, D., Just, W., Birk, R., Schmidt, R.R., Rothman, J.E. and Wieland, F.T. (1990). The rate of bulk flow from the Golgi to the plasma membrane. Cell 63, 259-267.
Kelly, R.B. (1990). Microtubules, membrane traffic and cell organization. Cell 61, 5-7.

Klausner, R.D., Donaldson, J.G. and Lippincott-Schwartz, J. (1992). Brefeldin A: insights into the control of membrane traffic and organelle structure. J. Cell Biol.116, 1071-1080.

Kobayashi, T. and Pagano, R.E. (1989). Lipid transport during mitosis. Alternative pathways for delivery of newly synthesized lipids to the cell surface. J. Biol. Chem. 264, 5966-5973.

Kobayashi, T., Pimplikar, S.W., Parton, R.G., Bhakdi, S. and Simons, K. (1992). Sphingolipid transport from the trans-Golgi network to the apical surface in permeabilized MDCK cells. FEBS Lett. 300, 227231.

Kreis, T.E. (1990). The role of microtubules in the organisation of the Golgi apparatus. Cell Motil. Cytoskel. 15, 67-70.

Lipsky, N.G. and Pagano, R.E. (1985a). Intracellular translocation of fluorescent sphingolipids in cultured fibroblasts: endogenously synthesized sphingomyelin and glucocerebroside analogues pass through the Golgi apparatus en route to the plasma membrane. J. Cell Biol. 100, 27-34.

Lipsky, N.G. and Pagano, R.E. (1985b). A vital stain for the Golgi apparatus. Science 228, 745-747.

Low, S.H., Tang, B.L., Wong, S.H. and Hong, W. (1992). Selective inhibition of protein targeting to the apical domain of MDCK cells by brefeldin A. J. Cell Biol. 118, 51-62.

Matter, K., Bucher, K. and Hauri, H.-P. (1990). Microtubule perturbation retards both the direct and the indirect apical pathway but does not affect sorting of plasma membrane proteins in intestinal epithelial cells (Caco2). $E M B O ~ J .9,3163-3170$

Miller-Prodraza, H. and Fishman, P.H. (1984). Effect of drugs and temperature on biosynthesis and transport of glycosphingolipids in cultured neurotumor cells. Biochim. Biophys. Acta 804, 44-51.

Mollenhauer, H.H., Morré, D.J. and Rowe, L.D. (1990). Alteration of intracellular traffic by monensin; mechanism, specificity and relationship to toxicity. Biochim. Biophys. Acta 1031, 225-246.

Oda, K., Fujiwara, T. and Ikehara, Y. (1990). Brefeldin A arrests the intracellular transport of viral envelope proteins in primary cultured rat hepatocytes and HepG2 cells. Biochem. J. 265, 161-167.

Parczyk, K., Haase, W. and Kondor-Koch, C. (1989). Microtubules are involved in the secretion of proteins at the apical cell surface of the polarized epithelial cell, Madin-Darby canine kidney. J. Biol. Chem. 264, 16837-16846.

Parczyk, K. and Kondor-Koch, C. (1989). The influence of pH on the vesicular traffic to the surface of the polarized epithelial cell, MDCK. Eur. J. Cell Biol. 48, 353-359.

Parton, R.G., Dotti, C.G., Bacallao, R., Kurtz, I., Simons, K. and Prydz, K. (1991). pH-induced microtubule-dependent redistribution of late endosomes in neuronal and epithelial cells. J. Cell Biol. 113, 261-274.

Rindler, M.J., Ivanov, I.E. and Sabatini, D.D. (1987). Microtubule acting drugs lead to the nonpolarized delivery of the influenza hemagglutinin to the cell surface of polarized Madin-Darby canine kidney cells. J. Cell Biol. 104, 231-241.

Rodriguez-Boulan, E., Paskiet, K.T., Salas, P.J.I. and Bard, E. (1984). Intracellular transport of influenza virus hemagglutinin to the apical surface of Madin-Darby canine kidney cells. J. Cell Biol. 98, 308-319.

Saito, M., Saito, M. and Rosenberg, A. (1985). Influence of monovalent cation transport on anabolism of glycosphingolipids in cultured human fibroblasts. Biochemistry 24, 3054-3059.

Salas, P.J.I., Misek, D.E., Vega-Salas, D.E., Gundersen, D., Cereijido, M. and Rodriguez-Boulan, E. (1986). Microtubules and actin filaments are not critically involved in the biogenesis of epithelial cell surface polarity. J. Cell Biol. 102, 1853-1867.

Sasaki, T. (1990). Glycolipid transfer protein and intracellular traffic of glucosylceramide. Experientia 46, 611-616.

Simons, K. and van Meer, G. (1988). Lipid sorting in epithelial cells. Biochemistry 27, 6197-6202.

Strous, G.J., Berger, E.G., van Kerkhof, P., Bosshart, H., Berger, B. and Geuze, H.J. (1991). Brefeldin A induces a microtubule-dependent fusion of galactosyltransferase-containing vesicles with the rough endoplasmic reticulum. Biol. Cell 71, 25-31.

Strous, G.J., van Kerkhof, P., van Meer, G., Rijnboutt, S. and Stoorvogel, W. (1993). Differential effects of brefeldin A on transport of secretory and lysosomal proteins. J. Biol. Chem., in press.

Stults, N.L., Fechheimer, M. and Cummings, R.D. (1989). Relationship 
between Golgi architecture and glycoprotein biosynthesis and transport in Chinese hamster ovary cells. J. Biol. Chem. 264, 19956-19966.

Trinchera, M., Fabbri, M. and Ghidoni, R. (1991). Topography of glycosyltransferases involved in the initial glycosylations of gangliosides. J. Biol. Chem. 266, 20907-20912.

Urbani, L. and Simoni, R.D. (1990). Cholesterol and vesicular stomatitis virus $\mathrm{G}$ protein take separate routes from the endoplasmic reticulum to the plasma membrane. J. Biol. Chem. 265, 1919-1923.

Vale, R.D. (1990). Microtubule-based motor proteins. Curr. Opin. Cell Biol. 2, 15-22.

van Echten, G. and Sandhoff, K. (1989). Modulation of ganglioside biosynthesis in primary cultured neurons. J. Neurochem. 52, 207-214.

van Echten, G., Iber, H., Stotz, H., Takatsuki, A. and Sandhoff, K. (1990). Uncoupling of ganglioside biosynthesis by brefeldin A. Eur. J. Cell Biol. 51, 135-139.

van Meer, G.and Burger, K.N.J. (1992). Sphingolipid trafficking-sorted out? Trends Cell Biol. 2, 332-337.

van Meer, G., Stelzer, E.H.K., Wijnaendts-van-Resandt, R.W. and Simons, K. (1987). Sorting of sphingolipids in epithelial (Madin-Darby canine kidney) cells. J. Cell Biol. 105, 1623-1635.

van 't Hof, W. and van Meer, G. (1990). Generation of lipid polarity in intestinal epithelial (Caco-2) cells: sphingolipid synthesis in the Golgi complex and sorting before vesicular traffic to the plasma membrane. $J$. Cell Biol. 111, 977-986.

van 't Hof, W., Silvius, J., Wieland, F. and van Meer, G. (1992). Epithelial sphingolipid sorting allows for extensive variation of the fatty acyl chain and the sphingosine backbone. Biochem. J. 283, 913-917.

van Zeijl, M.J.A.H. and Matlin, K.S. (1990). Microtubule perturbation inhibits intracellular transport of an apical membrane glycoprotein in a substrate-dependent manner in polarized Madin-Darby canine kidney epithelial cells. Cell Regul. 1, 921-936.

Young, W.W. Jr., Lutz, M.S., Mills, S.E. and Lechler-Osborn, S. (1990). Use of brefeldin A to define sites of glycosphingolipid synthesis: GA2/GM2/GD2 synthase is trans to the brefeldin A block. Proc. Nat. Acad. Sci. USA 87, 6838-6842.

Zizi, M., Fisher, R.S. and Grillo, F.G. (1991). Formation of cation channels in planar lipid bilayers by brefeldin A. J. Biol. Chem. 266, 18443-18445.

(Received 30 July 1992 - Accepted, in revised form, 20 November 1992) 